\title{
Appendicular fractures of traumatic etiology in dogs: 955 cases (2004-2013)
}

\author{
Fraturas apendiculares de etiologia traumática em cães: 955 casos (2004-2013)
}

\author{
Renato do Nascimento Libardoni ${ }^{I}$ Gabriele Maria Callegaro Serafini ${ }^{\mathrm{I}}$ \\ Carla de Oliveira ${ }^{\text {II }}$ Paula Ivanir Schimites ${ }^{\text {III }}$ Rafael Oliveira Chaves $^{\mathrm{I}}$ \\ João Pedro Scussel Feranti ${ }^{I}$ Cesar Augusto Soares Costa ${ }^{\text {III }}$ \\ Anne Santos do Amaral ${ }^{\mathrm{IV}}$ Alceu Gaspar Raiser ${ }^{\mathrm{IV}}$ André Vasconcelos Soares ${ }^{\mathrm{IV}^{*}}$
}

\section{ABSTRACT}

Orthopedic diseases are common in dogs and cats especially, those caused by traumatic injury. Overall, among the significant changes in this group, the fractures are the major cause of pain and dysfunction in dogs of all ages, sizes and breeds. Therefore, a retrospective study of dogs examined between January 2004 and December 2013 at the University Veterinary Hospital of Universidade Federal de Santa Maria, was conducted aiming to identify and determine the prevalence of appendicular fractures caused by trauma and characterizing the population/etiology. In a population of 1,200 dogs with suspected traumatic orthopedic diseases in the locomotor system, 955 (79.6\%) had appendicular fractures. Of the dogs $23.5 \%$ had fractures on the femur $(n=225)$, $23.4 \%$ had pelvic fractures ( $n=223$ ), $22 \%$ had tibial and fibular fractures $(n=210), 17.6 \%$ had radius and ulna fractures $(n=168)$, $7.5 \%$ had humeral fractures $(n=72)$ and $6 \%$ had distal limb fractures (tarsus, carpus, metacarpus, metatarsus and phalanges $(n=57))$. The most frequent cause was car accidents $(72.2 \%)$. Most affected dogs were male (52.5\%), juvenile (42\%), mixed breed $(51.4 \%)$ and small size $(42.7 \%)$. In conclusion, the profile of dogs with fractures in the Central Region of Rio Grande do Sul State is: male dogs, mixed breed, immature and small size, presenting femoral fractures by car accident.

Key words: orthopedics, retrospective study, appendicular fractures, bones, dog

\section{RESUMO}

Doenças ortopédicas são comuns em cães e gatos, especialmente, aquelas causadas por lesões traumáticas. De forma geral, dentre as alterações significativas desta margem, apontamse as fraturas como causa importante de dor e disfunção em cães de todas as idades, tamanhos e raças. Diante disso, um estudo retrospectivo de cães atendidos entre janeiro de 2004 e dezembro de 2013 no Hospital Veterinário Universitário da Universidade Federal de Santa Maria, foi realizado, objetivando identificar e determinar a prevalência das fraturas apendiculares decorrentes de traumatismo, caracterizando a população e a etiologia. De um total de 1.200 cães com suspeita de doença ortopédica de origem traumática no sistema locomotor, 955 (79,6\%) apresentaram fraturas apendiculares, sendo que 23,5\% foram fraturas do fêmur ( $n=225), 23,4 \%$ fraturas da pelve $(n=223), 22 \%$ fraturas da tíbia e da fibula ( $n=210), 17,6 \%$ fraturas do rádio e da ulna ( $n=168), 7,5 \%$ fraturas do úmero $(n=72)$ e $6 \%$ fraturas distais dos membros (tarso, carpo, metacarpo, metatarso e falanges $(n=57)$ ), decorrentes principalmente de acidentes automobilísticos (72,2\%). Os cães mais afetados foram machos (52,5\%), filhotes (42\%), sem raça definida $(51,4 \%)$, de porte pequeno $(42,7 \%)$. Conclui-se que o perfil de cães com fraturas na Região Central do Rio Grande do Sul é: cães machos, sem raça definida, imaturos, de pequeno porte, apresentando fratura de fêmur por acidente automobilístico.

Palavras-chave: ortopedia, estudo retrospectivo, fraturas apendiculares, ossos, cão.

\section{INTRODUCTION}

The healthy musculoskeletal system, with normal operation, is essential for the survival and well-being (McNEILL, 2011). However, this system is commonly affected by orthopedic diseases composed of fractures, joint diseases, injuries to muscles and tendons, metabolic alterations and

\footnotetext{
IPrograma de Pós-graduação em Medicina Veterinária, Centro de Ciências Rurais (CCR), Universidade Federal de Santa Maria (UFSM), Santa Maria, RS, Brasil.

${ }^{\text {IIC }}$ urso de Medicina Veterinária, Centro de Ciências Rurais (CCR), Universidade Federal de Santa Maria (UFSM), Santa Maria, RS, Brasil. IIIMédico Veterinário Autônomo, Santa Maria, RS, Brasil.

IV Departamento de Clínica de Pequenos Animais, Centro de Ciências Rurais (CCR), Universidade Federal de Santa Maria (UFSM), Av. Roraima, 1000, Camobi, 97105-900, Santa Maria, RS, Brasil. E-mail: decovas@hotmail.com. *Corresponding author. Received 02.18.15 Approved 08.04.15 Returned by the author 10.21.15 CR-2015-0219.R1
} 
infectious or neoplastic diseases (PIERMATTEI et al., 2006; SOUZA et al., 2011).

Orthopedic diseases are common in dogs and cats, especially those caused by traumatic injury (BEN ALI, 2013; ELZOMOR et al., 2014). Fractures mostly occur due to traumatic conditions resulting from car accidents, but they can also occur by ballistic missiles, fights and falls (SIMPSON, 2004; KUMAR et al., 2007).

Animals that present orthopedic problems are responsible for a significant percentage of the population (BEN ALI, 2013), once these diseases are a major cause of pain and dysfunction in dogs of all ages, sizes and breeds (SEAMAN \& SIMPSON, 2004; SHEARER, 2011). Thus, the management of the animal environment by the owner, promoting appropriate containment and protection measures for animals which use public spaces, plays an important role in the prevalence of injury (VIDANE et al., 2014). So, the factors that influence the result of a traumatic event include the cause of the injury, the extent and the distribution of kinetic energy discharged to the animal and the anatomical location of the lesion (McCARTNEY \& MacDONALD, 2006; HARASEN, 2009).

In order to the clinical professionals improve the diagnosis and the understanding of major diseases of particular organ system, it is extremely important to carry out retrospective and prospective studies to determine the prevalence of the most common diseases in a given geographic region (CHAVES et al., 2014). Knowing the types and frequency of fractures in domestic animals, the professionals in the area of orthopedics and veterinary physiotherapy can direct their attention to the improvement of fixation techniques, correction and stabilization of fractures with higher incidence, thus increasing the efficiency in the treatment and repair (VIDANE et al., 2014).

Based on this, due to lack of data on the characterization of appendicular fractures in dogs in Brazil, the aim of this study are: 1) identify and determine the prevalence of dogs with appendicular fractures arising from trauma treated between January 2004 and December 2013 at the University Veterinary Hospital of Universidade Federal de Santa Maria, emphasizing the information that characterizes the population (breed, age, gender and size) and 2) characterize the etiology.

\section{MATERIAL AND METHODS}

All orthopedic care records held at the University Veterinary Hospital (HVU) of Universidade Federal de Santa Maria (UFSM) were reviewed, between January 2004 and December 2013 (10 years). Dogs that had medical history, clinical and orthopedic examination of appendicular fractures of traumatic etiology, with diagnosis confirmed by radiographic examination were included in this research. From these records, it was evaluated the data referring to the type of disease and its location (anatomical structure affected), probable causing agent and the information that characterized the animal, such as breed, age, gender and weight. The choice of the information collected was based on other retrospective studies (FIGHERA et al., 2008a; SHEARER, 2011; SOUZA et al., 2011; MINAR et al., 2013; BENNOUR et al., 2014). The dogs were divided into four age groups: juvenile (less than one year old), young adult (between one and three years), mature adult (between three and 10 years) and geriatric (above 10 years), according to the methodology used by SHEARER (2011). In relation to size, they were classified as: miniature (less than $6 \mathrm{~kg}$ ), small (6 to $15 \mathrm{~kg}$ ), medium (15 to $25 \mathrm{~kg}$ ), large ( 25 to $45 \mathrm{~kg}$ ) and giant (more than $45 \mathrm{~kg}$ ). For this, it was used the criteria recognized by national and international literature (SLATTER, 2003; PIERMATTEI et al., 2006; FOSSUM, 2013). The obtained data were submitted to the frequency distribution analysis by Chi-square $X^{2}$ test. The significance level was set at $1 \%(\mathrm{P} \leq 0.01)$.

\section{RESULTS AND DISCUSSION}

In 10 years, 1,200 dogs were referred with suspected traumatic orthopedic disease of the locomotor system to the University Veterinary Hospital of the Universidade Federal de Santa Maria. BENNOUR et al. (2014) observed in a retrospective study that the appendicular fractures were the most prevalent alterations, corresponding to $67.8 \%$ of the dog population evaluated at the Veterinary Hospital of the University of Tripoli (Libya). The authors of this study observed that $955(79.6 \%)$ dogs presented appendicular fractures, and of these, $23.5 \%$ were femur fractures $(n=225), 23.4 \%$ fractures of the pelvis ( $n=223$ ), $22 \%$ fractures of the tibia and the fibula $(\mathrm{n}=210), 17.6 \%$ radius and ulna fractures $(\mathrm{n}=168), 7.5 \%$ humeral fractures $(\mathrm{n}=72)$ and $6 \%$ distal fractures of the limbs $(\mathrm{n}=57$ [tarsus $=8$; metatarsus $=19$; phalanges pelvic $=2$; carpus $=2$; metacarpus $=23$ and thoracic phalanges=3]). In $87(9.1 \%)$ cases, the dogs had more than one fracture: fracture of the pelvis and femur $(n=51)$; fracture of the femur and the tibia and fibula $(n=12)$; fracture of the pelvis, tibia and fibula $(n=8)$; fracture of the pelvis, femur and tibia and fibula $(n=6)$; femoral fracture and radius and ulna $(n=6)$; radius and ulna fractures and metacarpus $(n=2)$; fracture of the tibia and fibula and the radius and ulna $(\mathrm{n}=1)$, and fracture of the humerus and the radius and ulna fractures $(n=1)$.

To SOUZA et al. (2011), the hind limbs are twice more exposed to fracture than the forelimbs. 
However, MINAR et al. (2013) observed that $33.4 \%$ of the fractures have occurred in the hind limbs and $27.3 \%$ in the forelimb, or a relationship between pelvic: thoracic 1.2. However, in this study, there was an intermediate relationship, once fractures of the hind limbs represent $48.5 \%$ of the cases and the thoracic limbs, $28 \%$, resulting in a relationship between pelvic: thoracic 1.7 .

The femur is the most frequently affected bone, followed by the tibia and fibula (BEALE, 2004; KUMAR et al., 2007), when referring to the hind limbs. However, in the forelimb, radius and ulna are the bones with the most fractures (BENNOUR et al., 2014), due to low local muscle coverage (MILOVANCEV \& RALPHS, 2004). These data correspond to those observed by the authors of this study, which verified that femur fractures were the most prevalent, followed by the tibia and fibula fractures in the hind limbs and radius and ulna fractures, followed by humerus fractures were the most prevalent in forelimbs data that corroborate with MINAR et al. (2013). According to KUMAR et al. (2007), the highest prevalence of fractures in the hind limbs in dogs is correlated with anatomical conformation provided by the standing position of the animals, making them slower to react to trauma. Thus, during the effort of escaping, they end exposing the hind limbs to the main force of the impact. In addition, a trauma in the pelvic region of the animal produces injuries with less potential mortality, providing direct treatment to these animals.

About $20-30 \%$ of fractures in small animals are located in the pelvis, mainly due to car accidents, which affect dogs of any race, age and sex (BENNOUR et al., 2014). In the present study it was observed that $23.4 \%$ of the evaluated animals presented pelvic fractures. SOUZA et al. (2011) observed in their study that the fractures of the pelvis were responsible for $11.5 \%$ of orthopedic diseases of the hind limbs in the evaluated population of dogs.

Traumatic events are often observed as responsible for orthopedic disease in dogs and cats (FIGHERA et al., 2008b; STREETER et al., 2009), and fractures result mainly from motor vehicle accidents (VIDANE et al., 2014), ballistic projectiles, fights and falls (KUMAR et al., 2007). In this study, regarding the etiology of the trauma, the cause cannot be defined in 174 cases of fractures because the owners had not witnessed the moment of the event. However, of the 781 causes reported (Table 1), 72.2\% were due to motor vehicle accidents $(\mathrm{n}=564), 13.3 \%$ falls $(\mathrm{n}=104)$ and $7.3 \%$ bite $(n=57)$, or other causes $(7.2 \%, n=56)$, which included ballistic projectiles $(n=6)$, human aggression $(n=18)$ recoil $(n=12)$ and beat and/or stepped $(n=20)$. The authors of the study attribute the high incidence of trauma to the high number of dogs which have access to public roads and also to the owners who omit containment measures and protection in their homes and during rides.

In relation to the racial distribution, data showed wide variation, where 491 (51.4\%) had no defined breed and $464(48.6 \%)$ were purebred. Forty two dogs with different breeds showed fractures, and those with frequency equal or higher than $1.0 \%$ of the total included: Poodle $(7.5 \%, \mathrm{n}=72)$, Pinscher $(6.8 \%$, $\mathrm{n}=65)$ Dachshund $(6.3 \%, \mathrm{n}=61)$, Labrador Retriever $(2.5 \%, \mathrm{n}=24)$, Yorkshire $(2.4 \%, \mathrm{n}=23)$, Collie $(1.8 \%$, $\mathrm{n}=17)$, Australian Cattle Dog $(1.7 \%, \mathrm{n}=16)$, German Shepherd (1.7, $\mathrm{n}=16)$, Border Collie $(1.5 \%, \mathrm{n}=15)$, Fox $(1.4 \%, \mathrm{n}=13)$ Pointer $(1.4 \%, \mathrm{n}=13)$, Boxer $(1.3 \%, \mathrm{n}=12)$, Cocker Spaniel $(1.3 \%, \mathrm{n}=12)$ and Rottweiler $(1.3 \%, \mathrm{n}=12)$ (Table 2$)$. A study conducted at the Veterinary Hospital of Veterinary Medicine and Animal Husbandry School, UNESP Botucatu (São Paulo - Brazil) by SOUZA et al. (2011), the dogs with no defined breed consisted of the category with the most fractures of long bones, followed by Poodles, Pinschers and Dachshunds, similar to what was observed in this study. Additionally, it is noteworthy that Pinscher and Poodle breeds presented a higher prevalence of the radius and ulna fractures. MINAR et al. (2013), while evaluating the dogs referred to the Veterinary Medical Center of Chungbuk National

Table 1 - Distribution of frequencies of the most prevalent causes that resulted in appendicular fractures in dogs (Chi-square $X^{2}$ test. $\left.\mathrm{P} \leq 0,01\right)$.

\begin{tabular}{|c|c|c|c|c|c|}
\hline Fracture & Car accident & Falls & Bites & Others & Total \\
\hline Pelvis & $197(25.2 \%)$ & $4(0.5 \%)$ & $2(0.2 \%)$ & $0(0 \%)$ & $203(25,9 \%)$ \\
\hline Femur & $152(19.5 \%)$ & $18(2.3 \%)$ & $8(1 \%)$ & $6(0.8 \%)$ & $184(23.6 \%)$ \\
\hline Tibia/Fibula & $119(15.2 \%)$ & $16(2 \%)$ & $19(2.5 \%)$ & $19(2.5 \%)$ & $173(22.2 \%)$ \\
\hline Radius/Ulna & $50(6.4 \%)$ & $50(6.4 \%)$ & $19(2.5 \%)$ & $7(0.9 \%)$ & $126(16.2 \%)$ \\
\hline Humerus & $25(3.2 \%)$ & $6(0.8 \%)$ & $8(1 \%)$ & $12(1.5 \%)$ & $51(6.5 \%)$ \\
\hline DFL & $21(2.7 \%)$ & $10(1.3 \%)$ & $1(0.1 \%)$ & $12(1.5 \%)$ & $44(5.6 \%)$ \\
\hline Total & $564(72.2 \%)$ & $104(13.3 \%)$ & $57(7.3 \%)$ & $56(7.2 \%)$ & $781(100 \%)$ \\
\hline
\end{tabular}

DFL: Distal fractures of limbs. Analysis of frequencies with statistically significant results $(\mathrm{P} \leq 0.001)$.

Ciência Rural, v.46, n.3, mar, 2016. 
Table 2 - Distribution of the 14 most prevalent breeds of dogs with appendicular fractures of traumatic etiology.

\begin{tabular}{llllllll}
\hline Fracture & FP & FF & FTF & HF & FRU & DFL & Total \\
\hline Australian Cattle Dog & 0 & 6 & 5 & 3 & 1 & 1 & $16(1.7 \%)$ \\
Border Collie & 3 & 4 & 3 & 3 & 2 & 0 & $15(1.5 \%)$ \\
Boxer & 1 & 4 & 6 & 1 & 0 & 0 & $12(1.3 \%)$ \\
Cocker Spaniel & 5 & 4 & 0 & 1 & 2 & 0 & $12(1.3 \%)$ \\
Collie & 3 & 4 & 5 & 1 & 3 & 1 & $17(1.8 \%)$ \\
Dachshund & 25 & 12 & 12 & 3 & 5 & 4 & $61(6.3 \%)$ \\
Fox & 2 & 2 & 3 & 2 & 2 & 2 & $13(1.4 \%)$ \\
Labrador Retriever & 4 & 10 & 4 & 2 & 3 & 1 & $24(2.5 \%)$ \\
German Shepherd & 2 & 3 & 5 & 1 & 2 & 3 & $16(1.7 \%)$ \\
Pinscher & 14 & 7 & 8 & 4 & 29 & 3 & $65(6.8 \%)$ \\
Pointer & 1 & 1 & 6 & 2 & 1 & 2 & $13(1.4 \%)$ \\
Poodle & 19 & 10 & 13 & 2 & 23 & 5 & $72(7.5 \%)$ \\
Rottweiler & 2 & 6 & 2 & 1 & 1 & 0 & $12(1.3 \%)$ \\
Yorkshire & 5 & 5 & 4 & 0 & 6 & 3 & $23(2.4 \%)$ \\
Total & 86 & 78 & 76 & 26 & 80 & 25 & $371(38.9 \%)$ \\
\hline
\end{tabular}

FP: pelvic fractures; FF: femoral fractures; FTF: fractures of the tibia and fibula; HF: humeral fractures; FRU: fractures of radius and ulna; DFL: distal fractures of the limbs.

University (Korea), the most affected breeds by fractures were, in order of occurrence, Yorkshire, Poodle, Malts, Pekingese, German Spitz and dogs with no defined breed.

Regarding the distribution of age (Table 3), it was observed that $401(42 \%)$ were juvenile, 271 (28.4\%) mature adults, 238 (24.9\%) young adults and $45(4.7 \%)$ geriatric. In this study, about $2 / 3$ of the dogs showed the age of three years. Similar results were observed in other retrospective evaluations by SOUZA et al. (2011), BEN ALI (2013) and MINAR et al. (2013). When considering the age group, younger dogs were more prevalent as they were under development, with low density bones in osteogenesis phase, which can be fragile even for injuries of lower intensities (MINAR et al., 2013) and, due to the inability to avoid them (VIDANE et al., 2014).
Regarding gender, males $(52.5 \%, \mathrm{n}=501)$ were more prevalent than females $(47.5 \%, n=454)$ $(\mathrm{P}=0.016)$, likewise it was found by SOUZA et al. (2011), during the evaluation of 889 dogs with orthopedic diseases in pelvic limbs. There is no exact explanation for the higher prevalence of males, but that can be justified by the fact that this category of animals has more access to the streets, mainly in search of females in heat, making them more exposed to accidents or to be involved in fights with other males.

According to JOHNSON (2013), the size of the dog does not mean condition of predisposition to fractures. However, in this study, from $801 \mathrm{dogs}$ that had the weight informed, $115(14.3 \%)$ were of miniature size, $342(42.7 \%)$ small size, $192(23.9 \%)$ mid-size, $133(16,7 \%)$ large size and $19(2.4 \%)$ giant size (Table 4). This high incidence of small and

Table 3 - Distribution of the frequencies of the age groups of dogs with appendicular fractures (Chi-square $X^{2}$ test., $P \leq 0.01$ ).

\begin{tabular}{|c|c|c|c|c|c|}
\hline Fracture & Juvenile & Young adult & Muture adult & Geriatric & Total \\
\hline Pelvis & $70(7.3 \%)$ & $65(6.8 \%)$ & $71(7.5 \%)$ & $17(1.8 \%)$ & $223(23.4 \%)$ \\
\hline Femur & $133(13.9 \%)$ & $47(4.9 \%)$ & $42(4.4 \%)$ & $3(0.3 \%)$ & $225(23.5 \%)$ \\
\hline Tibia/Fibula & $80(8.4 \%)$ & $49(5.1 \%)$ & $68(7.1 \%)$ & $13(1.4 \%)$ & $210(22 \%)$ \\
\hline Radius/Ulna & $73(7.7 \%)$ & $47(4.9 \%)$ & $43(4.5 \%)$ & $5(0.5 \%)$ & $168(17.6 \%)$ \\
\hline Humerus & $28(2.9 \%)$ & $16(1.7 \%)$ & $24(2.5 \%)$ & $4(0.4 \%)$ & $72(7.5 \%)$ \\
\hline DFL & $17(1.8 \%)$ & $14(1.5 \%)$ & $23(2.4 \%)$ & $3(0.3 \%)$ & $57(6 \%)$ \\
\hline Total & $401(42 \%)$ & $238(24.9 \%)$ & $271(28.4 \%)$ & $45(4.7 \%)$ & $955(100 \%)$ \\
\hline
\end{tabular}

DFL: Distal fractures of limbs. Analysis of frequencies with statistically significant results $(\mathrm{P} \leq 0.001)$.

Ciência Rural, v.46, n.3, mar, 2016. 
Table 4 - Distribution of the frequencies of sizes of dogs with appendicular fractures (Chi-square $X^{2}$ test, $\mathrm{P} \leq 0.01$ ).

\begin{tabular}{|c|c|c|c|c|c|c|}
\hline Fraturas & Mini & Small & Medium & Large & Giant & Total \\
\hline Pelvis & $26(3.2 \%)$ & $97(12.1 \%)$ & $30(3.8 \%)$ & $22(2.8 \%)$ & $1(0.1 \%)$ & $176(22 \%)$ \\
\hline Femur & $13(1.6 \%)$ & $83(10.4 \%)$ & $50(6.2 \%)$ & $36(4.5 \%)$ & $12(1.5 \%)$ & $194(24.2 \%)$ \\
\hline Tibia/Fibula & $16(2 \%)$ & $78(9.7 \%)$ & $48(6 \%)$ & $32(4 \%)$ & $2(0.3 \%)$ & $176(22 \%$ \\
\hline Humerus & $6(0.7 \%)$ & $22(2.8 \%)$ & $26(3.2 \%)$ & $9(1.1 \%)$ & $1(0.1 \%)$ & $64(7,9 \%)$ \\
\hline Radio/Ulna & $47(5.9 \%)$ & $41(5.1 \%)$ & $29(3.6 \%)$ & $22(2.8 \%)$ & $3(0.4 \%)$ & $142(17.8 \%)$ \\
\hline DFL & $7(0.9 \%)$ & $21(2.6 \%)$ & $9(1.1 \%)$ & $12(1.5 \%)$ & $0(0 \%)$ & $49(6.1 \%)$ \\
\hline Total & $115(14,3 \%)$ & $342(42.7 \%)$ & $192(23,9 \%)$ & $133(16,7 \%)$ & $19(2.4 \%)$ & $801(100 \%)$ \\
\hline
\end{tabular}

DFL: Distal fractures of limbs. Analysis of frequencies with statistically significant results $(\mathrm{P} \leq 0.001)$.

miniature dogs that occurs in the Central Region of Rio Grande do Sul State is probably related to the increasing number of dogs residing in apartments with their owners. Furthermore, according to MILOVANCEV \& RALPHS (2004), small dogs with low muscle coverage in the limbs are more likely to appendicular fractures.

\section{CONCLUSION}

We conclude that the dogs profile with fractures in the Central Region of Rio Grande do Sul State region is: male dogs, without defined breed, immature, small size, with femur fractures by car accident.

\section{REFERENCES}

BEALE, B. Orthopedic clinical techniques femur fracture repair. Clinical Techniques in Small Animal Practice, v.19, n.3, p. 134-150, 2004.

BEN ALI, L.M. Incidence, occurrence, classification and outcome of small animal fractures: a Retrospective Study (2005-2010). International Scholarly and Scientific Research \& Innovation, v.7, n.3, p.519-524, 2013.

BENNOUR, E.M. et al. A retrospective study on appendicular fractures in dogs and cats in Tripoli - Libya. Journal of Veterinary Advances, v.4, n.3, p. 425-431, 2014.

CHAVES, R.O. et al. Neurological diseases in dogs examined at the Veterinary Teaching Hospital of the Federal University of Santa Maria, RS: 1.184 cases (2006-2013). Pesquisa Veterinária Brasileira, v.34, n.10, p.996-1001, 2014.

ELZOMOR, S.T. et al. Prevalence of femoral fractures in dogs and cats. Journal of the Egyptian Veterinary Medical Association, v.74, n.2, p. 269-278, 2014.

FIGHERA, R.A. et al. Causes of death and reasons for euthanasia in dogs from the midland region of the Midwest of Rio Grande do Sul State, Brazil (1965-2004). Pesquisa Veterinária Brasileira, v.28, n.4, p.223-230, 2008a.

FIGHERA, R.A. et al. Pathological aspects of 155 fatal cases of dogs victimized by motor vehicles accidents. Ciência Rural, v.38, n.5, p.1375-1380, 2008b.
FOSSUM, T.W. Small animal surgery. 4th.ed. St. Louis Missouri: Mosby Elsevier, 2013. 1619p.

HARASEN, G. Feline orthopedics. Canadian Veterinary Journal, v.50, n.6, p.669-670, 2009.

JOHNSON, A.L. Management of specific fractures. In: FOSSUM, T.W. Small animal surgery. 4th.ed. St. Louis, Missouri: Mosby Elsevier, 2013. p.1106-1214.

KUMAR, K. et al. Occurrence and pattern of long bone fractures in growing dogs with normal and osteopenic bones. Journal of Veterinary Medicine Series A, v.54, n.9, p.484-490, 2007.

McCARTNEY, W.T.; MacDONALD, B.J. Incidence of non-union in long bone fractures in 233 cats. International Journal of Applied Research in Veterinary Medicine, v.4, n.3, p.209-212, 2006.

McNEILL, E. Editorial. Veterinary Focus, v.21, n.2, p.1, 2011.

MILOVANCEV, M.; RALPHS, S.C. Radius/ulna fracture repair. Clinical Techniques in Small Animal Practice, v.19, n.3, p. 128-133, 2004.

MINAR, M. et al. Retrospective study on fractures in dogs. Journal Biomedical Research, v.14, n.3, p.140-144, 2013

PIERMATTEI, D.L. et al. Handbook of small animal orthopedics and fractur repair. 4th.ed. St. Louis, Missouri: Saunders Elsevier, 2006. 906p.

SEAMAN, J.A.; SIMPSON, A.M. Tibial fractures. Clinical Techniques in Small Animal Practice, v.19, n.3, p. 151-167, 2004.

SHEARER, Epidemiology of orthopedic disease. Veterinary Focus, v.21, n.2, p. 24-25, 2011.

SIMPSON, A.M. Fractures of the humerus. Clinical Techniques in Small Animal Practice, v.19, n.3, p. 120-127, 2004.

SLATTER, D. Textbook of small animal surgery. 3rd.ed. Philadelphia: Saunders Elsevier, 2003. 2713p.

SOUZA, M.M.D. et al. Orthopedic diseases of hind limbs in dogs: retrospective study. Ciência Rural, v.41, n.5, p.852-857, 2011.

STREETER, E.M. Evaluation of vehicular trauma in dogs: 239 cases (January-December 2001). Journal of the American Veterinary Medical Association, v.235, n.4, p.405-408, 2009.

VIDANE, A.S. et al. Incidence of fractures in the dogs and cats in Maputo (Mozambique) between 1998 and 2008. Ciência Animal Brasileira, v.15, n.4, p.490-494, 2014. 